\title{
Correction to: Density and thermal expansion coefficients of liquid and austenite phase in lamellar cast iron
}

\author{
Kristina Hellström, *Vasile-Lucian Diaconu, Attila Diószegi
}

School of Engineering, Jönköping University, Sweden

Copyright $\odot$ The Author(s), 2020, corrected publication [07/2020 of update].

This article is published with open access at Springer.com.

Correction to: CHINA FOUNDRY, Vol. 17 (2020) 127-136

https://doi.org/10.1007/s41230-020-0004-8

The original article can be found online at https://doi.org/10.1007/s41230-020-0004-8.

Open Access This article is distributed under the terms of the Creative Commons Attribution 4.0 International License (http://creativecommons.org/licenses/by/4.0/), which permits use, duplication, adaptation, distribution and reproduction in any medium or format, as long as you give appropriate credit to the original author(s) and the source, provide a link to the Creative Commons license and indicate if changes were made.

The article "Density and thermal expansion coefficients of liquid and austenite phase in lamellar cast iron", written by Kristina Hellström, Vasile-Lucian Diaconu, Attila Diószegi, was originally published Online First without Open Access. After publication in volume 17, issue 2, page 127-136, the author decided to opt for Open Choice and to make the article an Open Access publication. Therefore, the copyright of the article has been changed to (C) The Author(s) [2020] and the article is forthwith distributed under the terms of the Creative Commons Attribution 4.0 International License (http:// creativecommons.org/licenses/by/4.0/), which permits use, duplication, adaptation, distribution and reproduction in any medium or format, as long as you give appropriate credit to the original author(s) and the source, provide a link to the Creative Commons license, and indicate if changes were made.

The original version of this article was revised due to a retrospective Open Access order. 